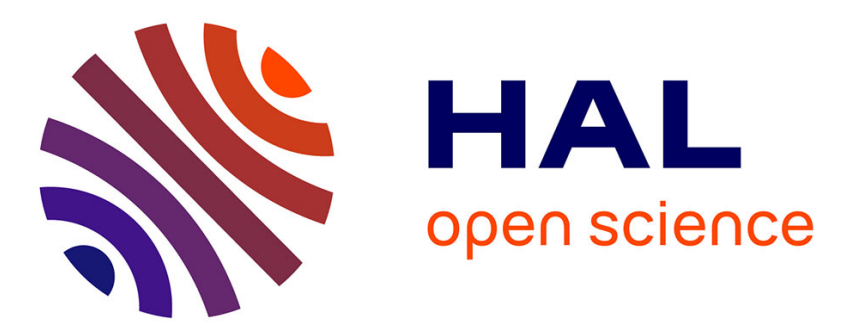

\title{
Sustained HBs seroconversion during lamivudine and adefovir dipivoxil combination therapy for lamivudine failure
}

Marianne Maynard, Parviz Parvaz, Sandra Durantel, Michèle Chevallier, Philippe Chevallier, Muriel Lot, Christian Trepo, Fabien Zoulim

\section{To cite this version:}

Marianne Maynard, Parviz Parvaz, Sandra Durantel, Michèle Chevallier, Philippe Chevallier, et al.. Sustained HBs seroconversion during lamivudine and adefovir dipivoxil combination therapy for lamivudine failure. Journal of Hepatology, 2005, 42 (2), pp.279-81. inserm-00135957

\section{HAL Id: inserm-00135957 https://www.hal.inserm.fr/inserm-00135957}

Submitted on 16 Mar 2007

HAL is a multi-disciplinary open access archive for the deposit and dissemination of scientific research documents, whether they are published or not. The documents may come from teaching and research institutions in France or abroad, or from public or private research centers.
L'archive ouverte pluridisciplinaire HAL, est destinée au dépôt et à la diffusion de documents scientifiques de niveau recherche, publiés ou non, émanant des établissements d'enseignement et de recherche français ou étrangers, des laboratoires publics ou privés. 


\section{Manuscript \# JHE-2004-0053}

Sustained HBs seroconversion during lamivudine and adefovir dipivoxil combination therapy for lamivudine failure

Marianne MAYNARD ${ }^{1}$, Parviz PARVAZ ${ }^{2}$, Sandra DURANTEL ${ }^{3}$, Michèle CHEVALLIER ${ }^{4}$, Philippe CHEVALLIER ${ }^{2}$, Muriel LOT $^{1}$, Christian TREPO ${ }^{1,3}$, Fabien ZOULIM ${ }^{1,3}$

${ }^{1}$ Liver Department, Hôtel-Dieu, Lyon, France

${ }^{2}$ Virology Laboratory, CHU Lyon, France

${ }^{3}$ INSERM U271, Lyon, France

${ }^{4}$ Pathology Laboratory, Marcel Merieux Laboratory, Lyon, France

Address for Correspondence

Fabien ZOULIM

INSERM U271 and Liver Department

151 Cours Albert Thomas

69003 Lyon, France

Phone : 33- 472681970

Fax : 33- 472681971

e.mail : zoulim@lyon.inserm.fr 
The efficacy of chronic hepatitis B therapy with lamivudine is limited by the emergence of drug resistant mutants (1). Mutations confering resistance to lamivudine are mainly located in the $\mathrm{C}$ domain of the reverse transcriptase within the YMDD motif, ie M204V or M204I, and may be associated with compensatory mutations in the C domain, ie V173L or L180M (2). Adefovir Dipivoxil (ADV) has recently been licensed for the treatment of chronic hepatitis $B$ in the United States and in Europe. ADV has demonstrated activity against wild type, pre-core mutant as well as lamivudine resistant strains of HBV (3-5). ADV has a proven clinical benefit in the treatment of lamivudine resistance with a significant inhibition of viral replication and improvement in liver function after 1 year of therapy. Despite the fact that ADV and lamivudine are not cross-resistant $(6,7)$, it is still debated whether the best treatment regimen for lamivudine resistance should rely on the switch to adefovir dipivoxil or on the addition of this drug to ongoing lamivudine (3-5).

In the Lyon Liver Department, we followed a cohort of 60 patients that received adefovir dipivoxil in a compassionate use program from the AFSSAPS (French Drug Agency) for lamivudine resistance. All patients received ADV in addition to lamivudine. The patients were prospectively followed up for a mean period of 10.3 months (range 3 months to 21 months). One of these patients lost serum HBsAg (Figure 1). This 41-year-old man with chronic hepatitis $B$ failed entecavir therapy in a clinical trial, then received lamivudine and became resistant to lamivudine. He was treated succesfully with ADV in addition to lamivudine. Lamivudine resistance was associated with the selection of a L180M+M204V polymerase mutant. After the addition of ADV, serum HBV DNA levels droped by more than $4 \log _{10}$ which was followed by HBsAg clearance after 22 months of combination therapy. This occurred simultaneously with $\mathrm{HBeAg}$ clearance and was not accompanied by an hepatitis flare. Moreover, anti-HBs antibody titers rose to $1000 \mathrm{mIU} / \mathrm{mL}$ after 32 months of the new treatment regimen. In parallel, HBV DNA declined below 100 copies / mL by a quantitative real time PCR assay. Analysis of intrahepatic viral DNA showed a significant decline of total HBV DNA and cccDNA (figure 1) which was accompanied by a decrease of the number of infected cells expressing viral antigens below the detection limit of immunostaining (data not shown). Evolution of serum HBsAg levels was parallel to that of HBV DNA in serum and liver. In parallel, liver histology analysis showed an improvement in both the activity index and fibrosis score. No virological or biochemical relapse was observed until the last visit three months after cessation of therapy.

It is very unlikely that this favorable outcome is due to spontaneous HBs seroconversion. Indeed, in the integrated analysis of phase III trials for lamivudine therapy, Lai et al observed $\mathrm{HBeAg}$ seroconversion in $10 \%$ up to $33 \%$ patients with lamivudine resistance who continued lamivudine and were followed for one up to 4 years respectively. However, no case of HBsAg clearance was noted (1). Furthermore, in two studies of ADV therapy for 
lamivudine resistant chronic hepatitis $\mathrm{B}$, no case of HBs seroconversion was observed in the 67 patients who received lamivudine plus placebo for 48 weeks $(3,4)$. Three patients lost $\mathrm{HBsAg}$ in these two clinical trials. All three received a combination of lamivudine plus adefovir dipivoxil. One patient out of 20 receiving this combination lost HBsAg after 44 weeks of therapy in the setting of non decompensated chronic hepatitis $B(4)$. In the other study, 2 patients out of 84 lost HBsAg during combination therapy, but both had undergone liver transplantation and received $\mathrm{HBlg}(3)$; it is therefore unknown if the addition of ADV was the only cause of HBsAg clearance.

In our case, viral load declined progressively for the first 19 months of the add-on therapy and then a sharp decline of viremia occurred and was followed by HBsAg clearance and subsequently by the rise in anti-HBsAb titers. None of these events was associated with ALT flares which could have suggested a cytotoxic $T$ cell attack of infected hepatocytes. Indeed, ALT levels became rapidly normal or at the level of the ULN after the addition of ADV. However, we cannot exclude killing by $T$ cells of a minor proportion of the liver since ALT levels were slightly elevated but close to the ULN before HBsAg elimination. Furthermore, $\mathrm{HBeAg}$ clearance was simultaneous to that of $\mathrm{HBsAg}$, and did not precede it. Interestingly, the longitudinal analysis of viral genome sequence, confirmed that lamivudine resistance was due to a known mutation in the viral polymerase, and neither a selection of basic core promoter or pre-core stop codon mutation nor a selection of an adefovir resistant mutant was observed throughout the evolution. Analysis of intrahepatic viral DNA showed a sharp decline of total intrahepatic viral DNA consistent with the inhibition of viral DNA synthesis. Furthermore, a significant decline of viral cccDNA by $2 \log 10$ copies/cell was observed in agreement with the results of another study in patients receiving adefovir dipivoxil (8). It was associated with a significant decline of HBV antigen - expressing cells below the detection limit of immunostaining assays. Therefore, one may hypothesize that the decline of intrahepatic viral load may have been associated with the sudden restoration of non cytolytic $\mathrm{TH} 1$ response followed by HBs seroconversion (9).

Furthermore, the combination of the virological and biochemical response was associated with an improvement of liver histology including a significant regression of liver fibrosis score. In conclusion, we have reported the case of a patient with chronic hepatitis $B$ failing lamivudine therapy who received a combination of adefovir dipivoxil and lamivudine and showed a dramatic drop in viral load both in the serum and the liver that was accompanied by HBsAg seroconversion and significant improvement in liver histology. In patients who previously failed lamivudine therapy, proactive antiviral treatment may lead to a beneficial virological and clinical effect.

\section{Acknowledgments}


This work was supported in part by the European Community contract QLRT2001-00977 (Inserm U271).

\section{References}

1. Lai CL, Dienstag J, Schiff E, Leung NW, Atkins M, Hunt C, Brown N, et al. Prevalence and clinical correlates of YMDD variants during lamivudine therapy for patients with chronic hepatitis B. Clin Infect Dis 2003;36:687-696.

2. Allen MI, Deslauriers M, Andrews CW, Tipples GA, Walters KA, Tyrell DLJ, Brown N, et al. Identification and characterization of mutations in hepatitis B virus resistant to Lamivudine. Hepatology 1998;27:1670-1677.

3. Perrillo R, Hann HW, Mutimer D, Willems B, Leung N, Lee WM, Moorat A, et al. Adefovir dipivoxil added to ongoing lamivudine in chronic hepatitis B with YMDD mutant hepatitis B virus. Gastroenterology 2004; $126: 81-90$

4. Peters MG, Hann Hw H, Martin P, Heathcote EJ, Buggisch P, Rubin R, Bourliere M, et al. Adefovir dipivoxil alone or in combination with lamivudine in patients with lamivudine-resistant chronic hepatitis $\mathrm{B}$. Gastroenterology 2004;126:91-101.

5. Zoulim F. Treatment of pre- and post-liver transplantation HBV infection: Should we aim at combination therapy? Hepatology 2003;38:1353-1355.

6. Angus P, Vaughan R, Xiong S, Yang H, Delaney W, Gibbs C, Brosgart C, et al. Resistance to adefovir dipivoxil therapy associated with the selection of a novel mutation in the HBV polymerase. Gastroenterology 2003;125:292-297.

7. Villeneuve JP, Durantel D, Durantel S, Westland C, Xiong S, Brosgart CL, Gibbs CS, et al. Selection of a hepatitis B virus strain resistant to adefovir in a liver transplantation patient. J Hepatol 2003;39:1085-1089.

8. Werle-Lapostolle B, Bowden S, Locarnini S, Wursthorn K, Petersen J, Lau G, Trepo C, et al. Persistence of cccDNA during the natural history of chronic hepatitis B and decline during adefovir dipivoxil therapy. Gastroenterology 2004;126:1750-1758.

9. Guidotti LG, Rochford R, Chung J, Shapiro M, Purcell R, Chisari FV. Viral clearance without destruction of infected cells during acute HBV infection. Science 1999;284:825-829.

Figure 1 Legend

Panel A. Evolution of biochemical markers and HBV DNA in a patient who failed entecavir and lamivudine therapy, and showed HBsAg seroconversion during lamivudine - adefovir dipivoxil combination therapy. Viral load was analyzed by versant HBV DNA 3.0 assay and expressed in $\log _{10} \mathrm{IU} / \mathrm{mL}$. Results of HBV serology are indicated below the graph. The results of viral polymerase gene sequence analysis are also indicated (WT, wild type sequence; L180M+M204V, lamivudine resistant mutant). The time points of liver biopsy (LB) are indicated by an arrow. Panel B. Results of quantification of serum HBsAg and anti-HBs during the course of the disease. Panel C. Results of intrahepatic HBV DNA quantification on sequential liver biopsies. Total viral DNA and cccDNA were detected using a real time PCR assay. Total viral DNA and cccDNA are expressed in copy number/cell. 